\title{
Equine osteoarthritis: A review of pathogenesis, diagnosis and treatment
}

\author{
N. Jansson
}

Section of Large Animal Surgery, Department of Clinical Studies, The Royal Veterinary and Agricultural University, Frederiksberg C, Denmark

\begin{abstract}
Summary
A brief review of pathogenesis, diagnosis and treatment of equine osteoarthritis is presented.

The role of synovitis in promoting articular cartilage degradation is discussed, and attention is drawn to the fact that chondrocytes themselves seem to be the major contributors of cartilage degradative enzymes.

Various methods of recognizing ongoing cartilage degeneration have been described. The use of these methods allow the establishment of an early diagnosis of osteoarthritis, thus improving treatment options and prognosis.

Treatment of osteoarthritis must be initiated in the early stages of the disease before articular cartilage degeneration has progressed to an irreversible level. Special attention is therefore given to the treatment of synovitis and conditions causing synovitis, as this will minimize the cartilage degradative effects of joint inflammation.
\end{abstract}

keywords: $\quad$ osteoarthritis, horse, degenerative joint disease

\section{Osteoarthritis des Pferdes: Ein Überblick über Pathogenese, Diagnose und Therapie}

Der Autor gibt einen Überblick über Pathogenese, Diagnose und Therapie der Osteoarthritis des Pferdes. Diese degenerative Gelenkserkrankung ist gekennzeichnet durch eine fortschreitende Schädigung des Gelenkknorpels, welcher nur in geringem Umfang regenerierfähig ist.

Die Pathogenese der Osteoarthritis ist weitgehend ungeklärt. Es wird angenommen, daß die akute und chronische Synovitis Auslöser der Erkrankung seien, indem sie den Zusammenbruch des Gelenkknorpels initieren. Weitere potentielle Ursachen sind direkte Traumen, welche ständig auf das betroffenen Gelenk einwirken, aber auch Chip-Frakturen. Die Entzündung der Synovialmembran scheint deshalb von großer Bedeutung zu sein, da hierbei einige Mediatoren freigesetzt werden, welche Zellschäden verursachen.

Zu diesen Mediatoren gehören Kinin, Histamin, Komplementfaktoren und Metaboliten des Gerinnungssystems. Sie locken Neutrophile und Mononukleäre Zellen an, welche wiederum lysosomale Enzyme freisetzen, so daß freie Radikale entstehen, welche den Gelenkknorpel enorm schädigen. An diesem Entzündungsprozeß sind auch verschiedene Zytokine, Leukotriene und Prostaglandine beteiligt, außerdem gibt es neutrale Metalloproteinasen, welche die Struktur des Gelenkknorpels schädigen, indem Proteoglykane und Kollagene abgebaut werden. Einige In-vitro-Versuche demonstrierten die Rolle des Interleukin-1 bei der Zerstörung des Gelenkknorpels, und des von Chondrozyten produzierten Stromelysins, einer der neutralen Metalloproteinasen. Die Bedeutung der Substanz P bei der Pathogenese der Osteoarthritis ist noch ungeklärt, es wird jedoch vermutet, daß sie die Zytokin- und Prostaglandinsynthese fördert.

Neben der Synovitis wird das rezidivierende Gelenktrauma als Auslöser der degenerativen Osteoarthritis diskutiert. Bei immer wiederkehrenden Traumen kommt es zum Anstieg der Arachidonsäurekonzentration in der Chondrozytenmembran sowie zu mechanischen Schäden am Gelenkknorpel.

Niebauer u.a. beschäftigten sich mit dem Einfluß der immunologischen Reaktivität auf degenerative Gelenksleiden. Sie isolierten Anti-Kollagen-Typ1-Antikörper und komplementgebundene Immunkomplexe aus der Synovialflüssigkeit von Pferden mit Chip-Frakturen oder Osteochondrosis dissecans.

Vermutlich kommt der Synovitis die Hauptrolle bei der Pathogenese der Osteoarthritis zu, daneben erscheint der Chondrozyt selbst die Hauptquelle Knorpel-degenerierender Enzyme zu sein.

Die Diagnose der denegerative Osteoarthritis hängt vom klinischen Erscheinunsbild des Falles ab. Neben Lahmheit, Schwellung des Gelenks und Beugeschmerz fällt oft eine eingeschränkte Beweglichkeit des betroffenen Gelenks auf. Leitungsanästhesien und intrasynoviale Anästhesien helfen, den Sitz der Erkrankung zu lokalisieren. Die radiologisch erkennbaren Veränderungen sind typisch und beinhalten marginale Osteophytenformation, subchondrale Knochensklerose, periosteale Proliferationen, Auflösung des subchondralen Knochens sowie eine Einengung des Gelenkspalts.

Ein wichtiges diagnostisches Hilfsmittel bei der Früherkennung der equinen Osteoarthritis ist die Thermographie, welche bereits geringgradige Entzündungen sichtbar macht. Speziellere Diagnosen werden durch die Szintigraphie erbracht, besonders dann, wenn andere Techniken keine genaue Lokalisation der Erkrankung erbringen. Wenn auf dem Röntgenbild noch keine Veränderungen sichtbar sind, kann eine Arthroskopie des betroffenen Gelenks bereits frühe Schäden wie z.B. Fibrillation und Erosion des Gelenkknorpels aufdecken. Die ultrasonographische Messung der Dicke des Gelenkknorpels liefert ebenfalls Hinweise auf degenerative Prozesse.

Als biochemische Marker der Osteoarthritis gelten die LDH-Isoenzymaktiviät in der Synovia, Glykosaminoglykane und die verschiedenen Produkte der Kollagensynthese. Eine Untersuchung der Synovialflüssigkeit auf Farbe, Konsistenz, Präzipitate und Proteingehalt gibt Hinweis auf eine Synovitis.

Die Behandlung der equinen Osteoarthritis solite sich auf die Unterbindung der primären Ursachen stützen, da eine Wiederherstellung des Gelenkknorpels kaum möglich ist. Zu den zahlreichen Behandlungsmethoden gehören : Ruhe, kontrollierte Arbeit, physikalische Therapie, intraartikuläre Injektionen von Kortikosteroiden, Hyaluronsäure, Orgotein und polysulphatierten Glykosaminoglykanen, orale oder parenterale Verabreichung von nichtsteroidalen Antiphlogistika sowie chirurgische Eingriffe in Form einer Kürettage, einer Arthrodese oder Fenestration des Gelenks. Es wurde auch versucht, Knorpelschäden durch autogene periostale und osteochondrale Transplantate aufzufüllen, die Resultate waren jedoch sehr variabel. Erste Erfolge wurden durch den Versuch einer Transplantation von Chondrozyten in einer Fibrin-Matrix erzielt.

Schlüsselwörter: Osteoarthritis, Arthrosis deformans, Pathogenese, Diagnose, Pferd 


\section{Introduction}

Lameness due to joint disease is an important cause of reduced performance in the athletic horse (Rossdale et al. 1985), and the economic impact on the racing industry is considerable (Jeffcott et al. 1982). Osteoarthritis (OA), or degenerative joint disease (DJD), is a chronic disorder characterized by progressive articular cartilage degeneration, and considering the limited potential of this tissue for regeneration, preventive measures, early diagnosis and treatment are of paramount importance (Pool and Meagher 1990).

Recognition of the mediators and products of inflammation as important factors in the initiation of articular cartilage degeneration has put an emphasis on the inflammatory response in the pathogenesis of equine OA (Palmer and Bertone 1994). Acute as well as chronic low-grade synovitis are believed to have the potential for initiating progressive cartilage breakdown, and therefore, adequate treatment of these conditions is essential in the prevention of $\mathrm{OA}$ (Todhunter and Lust 1990).

Recent progress has been made in the development of methods that may be valuable in establishing early diagnosis of equine OA. These methods include various markers of cartilage degradation (Rørvik and Grøndahl 1995) as well as non-invasive and invasive imaging techniques.

The purpose of this paper is to present a review of the pathogenesis, diagnosis and treatment of equine $O A$.

\section{Pathogenesis}

The pathogenesis of equine $\mathrm{OA}$ is still poorly understood, but advances have been made in the clarification of the sequence of events leading to the process of articular cartilage degeneration. Direct trauma as well as the influence on the articular cartilage by synovial membrane inflammation (synovitis) are believed to be important pathways for cartilage degeneration (Mcllwraith 1982, 1987a; Clyne 1987; Mcllwraith and Vachon 1988; Pool and Meagher 1990).

This is especially true in high-motion joints such as the carpal and fetlock joints (Mcllwraith 1982, 1987a). In low-motion joints such as the distal intertarsal joints and the proximal interphalangeal joint, repetitive direct trauma to the cartilage could be the main etiologic factor (Mc/lwraith 1982, 1987a; Mcllwraith and Vachon 1988).

The relationship between synovitis and articular cartilage degeneration is complex and not fully elucidated (Todhunter and Lust 1990; Palmer and Bertone 1994). Articular cartilage is an avascular tissue and therefore incapable of hosting an inflammatory response, and it is the reaction of this tissue to synovial membrane inflammation that will be discussed below.

Synovitis, of traumatic or septic origin, results in the release of several mediators of inflammation into the synovial fluid (Todhunter and Lust 1990; Palmer and Bertone 1994). These mediators include kinin, histamine, complement factors and byproducts of the clotting and fibrinolytic systems. Neutrophils and mononuclear cells are attracted, infiltrate the synovial membrane as well as the synovial fluid, and these cells release lysosomal enzymes and oxygen-derived free radicals (ODFR). Lysosomal enzymes and ODFR are apparently able to degrade cartilage components directly (Auer 1989; Palmer and Bertone 1994). Additionally stimulation of synoviocytes, chondrocytes and macrophages results in the synthesis of various cytokines and metabolites of arachidonic acid (prostaglandins and leukotrienes), thus exacerbating the inflammatory response. Cytokines such as interleukin-1 (IL-1) and tumor necrosis factor (TNF) activate chondrocytic enzyme synthesis and release, and these chondrocyte-derived enzymes include stromelysin, collagenase and gelatinase, collectively known as neutral metalloproteinases (Caron 1992; Price et al. 1992; Palmer and Bertone 1994). Neutral metalloproteinases are cartilage matrix degradative enzymes; stromelysin acts by degrading proteoglycan while collagenase and gelatinase degrade collagen. The focus is therefore on the chondrocyte itself as the main mediator of cartilage degradation (Caron 1992; May et al. 1992a; Price et al. 1992).

$\mathrm{IL}-1$ has been isolated from synovial fluid in horses with naturally occurring OA (Morris et al. 1990). This finding has been supported by others (Alwan et al. 1991a). The effect of IL-1 on equine cartilage has been investigated, using in vitro techniques (May et al. 1992b; Morris and Treadwell 1994), and these studies showed an increase in the production of chondrocyte-derived stromelysin. Further to this, it has been proposed that naturally occurring inhibitors of $\mathrm{IL}-1$ in the synovial fluid may play an important role in controlling IL-1 activity in the joint, thereby influencing cartilage response to increased production of $\mathrm{IL}-1$ (May et al. 1992c).

Articular cartilage contains naturally occurring inhibitors of metalloproteinases (TIMPs), and under normal circumstances, the TIMPs and metalloproteinases are believed to control proteoglycan and collagen turnover in the cartilage matrix (Palmer and Bertone 1994). Synovitis disturbs this balance by stimulating the chondrocytes to further synthesis of metalloproteinases, thus enhancing cartilage degradation.

Apart from chondrocytes, synoviocytes and infiltrating leukocytes also are sources of cartilage degradative enzymes, but substantial inactivation of these enzymes occurs by inhibitors in the synovial fluid such as $\mathrm{a}_{2}$-macroglobulin (Caron 1992).

The role of the neurotransmitter substance $P$ in the pathogenesis of equine OA has recently been discussed (Caron et al. 1992). In this study, it was shown that substance $P$ concentrations were significantly elevated in the synovial fluid of osteoarthritic middle carpal joints, compared with normal middle carpal joints in horses. The mechanism by which substance $P$ acts in the pathogenesis of equine $O A$ is unknown, but it has been suggested that it may induce increased synthesis of cytokines and prostaglandins (Caron et al. 1992).

As mentioned above, trauma plays a certain role in the development of equine $\mathrm{OA}$, and although inflammation-mediated cartilage matrix degradation seems to be the primary 


\section{Introduction}

Lameness due to joint disease is an important cause of reduced performance in the athletic horse (Rossdale et al. 1985), and the economic impact on the racing industry is considerable (Jeffcott et al. 1982). Osteoarthritis (OA), or degenerative joint disease (DJD), is a chronic disorder characterized by progressive articular cartilage degeneration, and considering the limited potential of this tissue for regeneration, preventive measures, early diagnosis and treatment are of paramount importance (Pool and Meagher 1990).

Recognition of the mediators and products of inflammation as important factors in the initiation of articular cartilage degeneration has put an emphasis on the inflammatory response in the pathogenesis of equine OA (Palmer and Bertone 1994). Acute as well as chronic low-grade synovitis are believed to have the potential for initiating progressive cartilage breakdown, and therefore, adequate treatment of these conditions is essential in the prevention of $O A$ (Todhunter and Lust 1990).

Recent progress has been made in the development of methods that may be valuable in establishing early diagnosis of equine OA. These methods include various markers of cartilage degradation (Rørvik and Grøndah/ 1995) as well as non-invasive and invasive imaging techniques.

The purpose of this paper is to present a review of the pathogenesis, diagnosis and treatment of equine $\mathrm{OA}$.

\section{Pathogenesis}

The pathogenesis of equine $O A$ is still poorly understood, but advances have been made in the clarification of the sequence of events leading to the process of articular cartilage degeneration. Direct trauma as well as the influence on the articular cartilage by synovial membrane inflammation (synovitis) are believed to be important pathways for cartilage degeneration (Mcl/wraith 1982, 1987a; Clyne 1987; Mcllwraith and Vachon 1988; Pool and Meagher 1990).

This is especially true in high-motion joints such as the carpal and fetlock joints (Mcllwraith 1982, 1987a). In low-motion joints such as the distal intertarsal joints and the proximal interphalangeal joint, repetitive direct trauma to the cartilage could be the main etiologic factor (Mc/lwraith 1982 , 1987a; Mcllwraith and Vachon 1988).

The relationship between synovitis and articular cartilage degeneration is complex and not fully elucidated (Todhunter and Lust 1990; Palmer and Bertone 1994). Articular cartilage is an avascular tissue and therefore incapable of hosting an inflammatory response, and it is the reaction of this tissue to synovial membrane inflammation that will be discussed below.

Synovitis, of traumatic or septic origin, results in the release of several mediators of inflammation into the synovial fluid (Todhunter and Lust 1990; Palmer and Bertone 1994). These mediators include kinin, histamine, complement factors and byproducts of the clotting and fibrinolytic systems. Neutrophils and mononuclear cells are attracted, infiltrate the synovial membrane as well as the synovial fluid, and these cells release lysosomal enzymes and oxygen-derived free radicals (ODFR). Lysosomal enzymes and ODFR are apparently able to degrade cartilage components directly (Auer 1989; Palmer and Bertone 1994). Additionally stimulation of synoviocytes, chondrocytes and macrophages results in the synthesis of various cytokines and metabolites of arachidonic acid (prostaglandins and leukotrienes), thus exacerbating the inflammatory response. Cytokines such as interleukin-1 ( $\mid \mathrm{L}-1)$ and tumor necrosis factor (TNF) activate chondrocytic enzyme synthesis and release, and these chondrocyte-derived enzymes include stromelysin, collagenase and gelatinase, collectively known as neutral metalloproteinases (Caron 1992; Price et al. 1992; Palmer and Bertone 1994). Neutral metalloproteinases are cartilage matrix degradative enzymes; stromelysin acts by degrading proteoglycan while collagenase and gelatinase degrade collagen. The focus is therefore on the chondrocyte itself as the main mediator of cartilage degradation (Caron 1992; May et al. 1992a; Price et al. 1992).

IL-1 has been isolated from synovial fluid in horses with naturally occurring OA (Morris et al. 1990). This finding has been supported by others (Alwan et al. 1991a). The effect of IL-1 on equine cartilage has been investigated, using in vitro techniques (May et al. 1992b; Morris and Treadwell 1994), and these studies showed an increase in the production of chondrocyte-derived stromelysin. Further to this, it has been proposed that naturally occurring inhibitors of $\mathrm{IL}-1$ in the synovial fluid may play an important role in controlling IL-1 activity in the joint, thereby influencing cartilage response to increased production of $\mathrm{IL}-1$ (May et al. 1992c).

Articular cartilage contains naturally occurring inhibitors of metalloproteinases (TIMPS), and under normal circumstances, the TIMPs and metalloproteinases are believed to control proteoglycan and collagen turnover in the cartilage matrix (Palmer and Bertone 1994). Synovitis disturbs this balance by stimulating the chondrocytes to further synthesis of metalloproteinases, thus enhancing cartilage degradation.

Apart from chondrocytes, synoviocytes and infiltrating leukocytes also are sources of cartilage degradative enzymes, but substantial inactivation of these enzymes occurs by inhibitors in the synovial fluid such as $a_{2}$-macroglobulin (Caron 1992).

The role of the neurotransmitter substance $P$ in the pathogenesis of equine OA has recently been discussed (Caron et al. 1992). In this study, it was shown that substance $P$ concentrations were significantly elevated in the synovial fluid of osteoarthritic middle carpal joints, compared with normal middle carpal joints in horses. The mechanism by which substance $P$ acts in the pathogenesis of equine $O A$ is unknown, but it has been suggested that it may induce increased synthesis of cytokines and prostaglandins (Caron et al. 1992).

As mentioned above, trauma plays a certain role in the development of equine $\mathrm{OA}$, and although inflammation-mediated cartilage matrix degradation seems to be the primary 
pathway, it has been shown that repetitive trauma to cartilage enhances arachidonic acid concentration in chondrocyte membranes, thereby indicating some direct influence of mechanical impact on chondrocyte metabolism (Chrisman et al. 1981). Trauma may also damage the articular cartilage in a more direct physical manner (Mc/lwraith 1982).

It has been suggested that immunologic reactivity might be involved in the mechanisms of chronic inflammation and progressive cartilage degradation in equine OA (Niebauer et al. 1988). These authors isolated anticollagen type-I antibodies and complement-binding immune complexes from synovial fluid samples of horses affected with secondary OA as a sequel to chip fractures or osteochondritis dissecans. Type $I$ is the primary collagen of bone tissue and is not a constituent of equine articular cartilage, in which type $\|$ is the primary collagen (Vachon et al. 1990; Palmer and Bertone 1994). Anticollagen type-I antibodies are therefore indicative of exposure of bone tissue to the joint cavity. In the study by Niebauer et al. (1988), only a few horses had anticollagen type-II antibodies, a finding that was attributed to the presumption that joints are exposed under normal circumstances to small amounts of cartilage debris. Exposure of subchondral bone takes place only in cases of severe trauma, such as chip fractures. The role of immunologic reactivity in equine $\mathrm{OA}$ other than secondary $\mathrm{OA}$ as a sequel to chip fractures or osteochondritis dissecans is uncertain.

Oxygen-derived free radicals (ODFR) are powerful tissuedamaging inflammatory products whose generation in the joint has been considered important in the pathogenesis of equine OA (Auer 1989). These inflammatory products are characterized by their ability to damage tissue directly (VanSteenhouse 1987), and it has been proposed that they may initiate articular cartilage degradation (Auer 1989). ODFR are derived either from activated neutrophil leukocytes or from an ischemia-reperfusion cycle. The latter pathway seems to be the most important in the pathogenesis of equine exercise-induced OA (Auer 1989). The same author suggests that fluctuations in the synovial fluid oxygen tension during exercise may generate continuous ischemia-reperfusion cycles, thereby generating ODFR in the joint. These ODFR then react directly with cartilage components, thus initiating articular cartilage degradation. In addition, ODFR are believed to influence the activity of cyclo-oxygenase, the enzyme controlling prostaglandin synthesis (Cleland 1984), and this interaction could be important to the inflammatory response. In short, ischemia-reperfusion injuries can be explained as follows: Ischemia results in local hypoxia which leads to a reduction of mitochondrial oxidative phosphorylation. As a consequence of this, the concentration of cellular AMP increases, and AMP is subsequently metabolized to hypoxanthine and xanthine. In addition, hypoxia results in increased levels of cellular xanthine oxidase. Reperfusion causes oxygen tension to increase, and hypoxanthine and xanthine oxidase reduce molecular oxygen to the superoxide radical. This radical is then part of the process leading to the formation of the highly reactive hydroxyl radi- cal. The exact role of ODFR in the pathogenesis of equine $\mathrm{OA}$ is at the present time not fully elucidated and warrants further investigations.

In summary, synovial membrane inflammation (synovitis) seems to play a major role in initiation and development of cartilage degeneration, the hallmark of equine $\mathrm{OA}$. The primary source of cartilage degradative enzymes is believed to be the chondrocyte itself.

\section{Diagnosis}

In a clinical setting, the manifestations of equine $O A$ will vary with the stage of the condition and the degree of joint inflammation (Mcl/wraith 1982, 1987a). Dependent on these factors, the clinical signs may include varying degrees of lameness, heat, swelling, pain on flexion, and decreased range of joint motion. Confirmation that the lameness is referable to a given joint is often obtained by nerve blocks or intrasynovial analgesia. Once the problem is localized, it is customary to perform a radiographic examination of the joints involved.

The radiographic signs of equine $\mathrm{OA}$ are generally acknowledged and well documented (O'Brien et al. 1971; Mcllwraith 1982, 1987a). They include marginal osteophyte formation, subchondral bone sclerosis, adjacent periosteal proliferation, and narrowing or loss of joint space. Subchondral bone lysis is a unique feature of $O A$ in low-motion joints (Pool and Meagher 1990).

It is generally accepted that marked articular cartilage degeneration can be present despite normal radiographic appearance of the joint. It is this fact, that has prompted the search for other diagnostic techniques.

Thermography is a non-invasive method which measures infrared emission from the body, and this technique has a high sensitivity as to detection of low-grade inflammation (Purohit 1980; Purohit and McCoy 1980). Although the technique has limited specificity, it has been suggested as a reliable method for early diagnosis of equine OA (Vaden et al. 1980). Thermography can demonstrate vascular changes due to joint inflammation, but no specific information on cartilage degeneration is obtained by this technique. The method should therefore only be used as an adjunct to more specific diagnostic techniques.

Nuclear scintigraphy is a non-invasive imaging technique which consists of injecting a radiopharmaceutical intravenously and using a gamma camera to detect and depict emitted radiation from the body (Barbee and Allen 1990). The method has primarily been used for diagnosing cases of lameness when other diagnostic techniques have failed to localize the problem (Devous and Twardock 1984; Lamb and Koblik 1988; Chambers et al. 1995). "Hot spots" of increased activity such as an inflamed or degenerated joint can be identified by this method. Nuclear scintigraphy is sensitive but lacks specificity as to ongoing cartilage degeneration, and this fact limits its usefulness in diagnosing equine $\mathrm{OA}$.

Arthroscopy is an invasive, imaging technique and allows the direct assessment of the articular cartilage (Mcllwraith 
1990). Degenerative changes in the cartilage can be recognized before radiographic evidence of OA occurs, and the typical candidate for diagnostic arthroscopy has a lameness localized in a given joint with no radiographic signs of pathology. Cartilage fibrillation and erosive changes can be identified using this technique, and arthroscopy has gained widespread use in diagnosing early $O A$ and evaluating the extent and character of degenerative cartilage changes. The major disadvantage of this technique is the need for general anesthesia.

Recently, the use of ultrasonography has been proposed as a noninvasive means to evaluate articular cartilage thickness in the horse (Jorgensen 1994). The method has been adapted from human medicine where ultrasonography is an integral part of the diagnostic workup in patients with various joint diseases (Jonsson et al. 1992). The applicability of the method is limited to cartilage surfaces which lie directly under the skin such as in the dorsal part of the metacarpo/metatarsophalangeal joint and certain parts of the tarsocrural joint. Preliminary results with this technique indicate that articular cartilage degeneration can be recognized ultrasonographically as a general or local thinning of this tissue. Further work is needed before the clinical usefulness of the technique can be fully assessed.

Various biochemical markers of cartilage degeneration have been employed in human medicine, but only a few of these have been investigated in the horse (Rørvik and Grøndahl 1995). Lactate dehydrogenase (LDH) isoenzyme activity in the synovial fluid has been suggested as a marker of cartilage degeneration (Rejnö 1976; Thorén-Tolling et al. 1983), but more recent studies have failed to verify the value of this test (Gängel and Rahn 1992; Mcllwraith 1993; Schwierczena et al. 1993).

Glycosaminoglycans (GAGs) (keratan sulfate and chondroitin sulfate) are part of the proteoglycan molecule in the articular cartilage matrix. Increased levels of these substances have been found in the synovial fluid of horses with naturally occurring OA (Alwan et al. 1990, 1991b; Little et al. 1990). This fact indicates that GAGs can be used as markers of cartilage breakdown in horses, a presumption which has been supported by experimental data (Todhunter et al. 1993a).

Increased collagen synthesis in the articular cartilage of an osteoarthritic joint results in diffusion into the synovial fluid of aminoterminal and C-terminal propeptides. These propeptides are generated when procollagen is converted to collagen. In humans, type II collagen C-terminal propeptide has been suggested as a marker of increased cartilage turnover in osteoarthritic joints (Shinmei et al. 1991). Similarly, type III collagen aminoterminal propeptide has been identified as a marker of joint capsule fibrosis in dogs with hip dysplasia and OA in the hip joint (Madsen et al. 1990). The author of this publication is part of a team conducting an experimental study of the role of collagen propeptides in horses with $\mathrm{OA}$, and preliminary results indicate that these substances also can be used as markers of joint degeneration in horses.
Further to the role of ODFR in the pathogenesis of equine $\mathrm{OA}$, hydrogen peroxide scavenging abiity of synovial fluid has been found to be significantly increased in osteoarthritic compared with normal joints (Little et al. 1992). In that study, scavenging ability was significantly associated with the degree of cartilage erosive changes, indicating that the method could be used as a marker of cartilage degradation in equine joint disease.

The presence of cartilage fragments in the synovial fluid has been proposed as a means to identify cartilage breakdown in horses (Tew 1982). Not only the presence but also the character of the fragments has been used for identifying cartilage degradation; noncellular fragments were reported to be indicative of superficial cartilage damage, whereas deeper damage supposedly could be evidenced by particles containing chondrocytes and perhaps even subchondral bone tissue (Mcl/wraith 1987b, 1993). This method is now rarely used, because of difficulties in interpreting the results. Other synovial fluid parameters that have been employed when diagnosing equine joint disease include total protein content, relative viscosity, mucinous precipitate quality and white cell count (Mc/lwraith 1987b). Merely being able to indicate the presence of joint inflammation, these methods are unreliable in staging the disease, as to extent of cartilage degradation and should therefore, primarily be used as adjuncts to some of the more specific diagnostic techniques outlined above.

\section{Treatment}

The treatment options of equine $\mathrm{OA}$ are ruled by the fact that articular cartilage has limited potential for regeneration, and accordingly, the greatest importance has been attached to treatment of primary causes such as intra-articular fractures, septic arthritis, osteochondritis dissecans, and traumatic synovitis (Mcllwraith 1982, 1987a; Mcl/wraith and Vachon 1988). Once articular cartilage degeneration has progressed to a certain level, the possibilities of total joint rehabilitation are believed to be limited, and, at this stage, only palliative treatment options realistically exist.

The various treatment methods are discussed briefly below. Rest, controlled exercise, and physical therapy are generally accepted as important parts of the management of joint inflammation in the horse (Mcllwraith and Vachon 1988; Palmer and Bertone 1994). However, these treatment modalities are often combined with more specific medical therapies whose action primarily is to limit synovitis and thereby protect the articular cartilage from the deleterious effects of joint inflammation.

Intra-articular administration of corticosteroids has been used widely in the treatment of equine joint disease ( $\mathrm{Mcll}$ wraith 1982). These substances exert powerful anti-inflammatory effects through lysosomal stabilization, blockage of phospholipase $A_{2}$, and inhibition of leucocyte migration (Palmer and Bertone 1994), and this effective suppression of the inflammatory response in the joint is the reason why 
corticosteroid administration results in a dramatic decrease in joint swelling and pain. However, several studies have shown that intra-articular administration of corticosteroids results in degenerative changes in the articular cartilage (Chunekamrai et al. 1989; Trotter et al. 1991; Shoemaker et al. 1992), and this deleterious effect should be considered when using these drugs for the treatment of OA. Perhaps the best way to overcome long-term side-effects of corticosteroid administration is to ensure stall rest or limited exercise during the first few weeks after treatment. Although the aim of corticosteroid treatment ideally is to reduce joint inflammation and thus prevent progressive cartilage degeneration, these drugs can also be used as palliative medication in the treatment of later stages of $O A$ when cartilage degeneration is already present. The advent of alternative medications has, however, limited the use of corticosteroids in the treatment of equine joint disease.

Systemic administration of non-steroidal anti-inflammatory drugs (NSAIDs) dampens joint inflammation and reduces pain (Palmer and Bertone 1994). These prostaglandin inhibitors act by blocking the cyclo-oxygenase enzyme of the arachidonic acid pathway, but they have no direct positive effect on articular cartilage degeneration (Mc/lwraith 1987a). Like corticosteroids, their main effect is that of reducing joint inflammation. In the face of already existing cartilage degeneration, these drugs can merely be used as palliative medication. Evidence exists from human medicine that some NSAIDs have a negative effect on cartilage metabolism. Although similar studies have not been performed on horses, this possible side-effect of NSAID administration could be important. These drugs are often used to prevent lameness in horses in training, but the effect on the articular cartilage of such long-term administration is presently unknown.

Intra-articular administration of exogenous high molecular weight hyaluronic acid $(\mathrm{HA})$ has gained widespread use in the treatment of acute synovitis in the horse (Mcllwraith 1987a; Howard and Mcl/wraith 1993). HA is believed to control the diffusion of various solutes via steric hindrance and to be important to certain cell-to-cell and cell-to-matrix interactions via specific membrane receptors (Palmer and Bertone 1994). in doing so, it reduces the inflammatory response in the joint. In cases of naturally occurring OA as well as in experimental studies, HA has been shown to improve the clinical signs of OA (Rose 1979; Auer et al. 1980; Gingerich et al. 1981). In a recent study using a cartilage explant system, a chondroprotective effect of HA was suggested in that a decrease in IL-1-mediated proteoglycan release from bovine articular cartilage was observed after addition of HA to the culture system (Morris et al. 1992). Further to this, it has been demonstrated that HA reduces the cartilage degradative effect of intra-articularly administered corticosteroids (Lindholm 1987). Again, HA treatment should be employed before cartilage degeneration becomes a problem, and although improvement of the clinical signs of OA may occur with this drug, no beneficial effect on already existing cartilage degeneration has been observed.
Polysulphated glycosaminoglycan (PSGAG) is composed of repeating units of hexosamine and hexuronic acid, and treatment with this drug is believed to inhibit cartilage matrix degradative enzymes and to stimulate synthesis of cartilage matrix components (Hamm and Wynn Jones 1988; Todhunter and Lust 1994). Both intra-articular and intramuscular applications of PSGAG have been used, and dose levels and intervals have been established (Hamm and Wynn Jones 1988). The usefulness of the drug in ameliorating the clinical signs of equine $\mathrm{OA}$ is generally recognized (Collins 1989). The chondroprotective effect of PSGAG has been shown in an experimental study (Yovich et al. 1987), but in that same study, no stimulation of cartilage matrix synthesis was observed using a cartilage-defect model. In another study, a positive effect of PSGAG treatment on the development of OA in exercised ponies with experimentally created osteochondral defects was reported (Todhunter et al. 1993b). In a tissue culture study, PSGAG was shown to increase net collagen and glycosaminoglycan synthesis by normal and arthritic cartilage (Glade 1990). In contrast to this, more recent studies have failed to indicate an anabolic effect of PSGAG (Caron et al. 1991, 1993). These somewhat conflicting data necessitate further investigations into the role of PSGAG in the treatment of equine OA. Perhaps this drug is more effective in prevention than in treatment of cartilage degeneration (Palmer and Bertone 1994; Todhunter and Lust 1994).

Orgotein exerts superoxide dismutase activity and has antiinflammatory effects (Mcl/wraith and Vachon 1988). It scavenges the superoxide radical, thereby inhibiting ODFRmediated tissue damage. Results from intra-articular application of orgotein in the treatment of traumatic arthritis have been reported (Ahlengard et al. 1978; Rydén et al. 1987), and the reported data suggest that this substance can be used as an effective anti-inflammatory drug in the treatment of acute synovitis. Its value in the management of $\mathrm{OA}$ is, however, still uncertain (Mc/lwraith and Vachon 1988). Adverse reactions to intra-articular administration of orgotein have been described (Wagner et al. 1982), but the significance of these is unclear.

Surgical treatment of equine $O A$ includes joint curettage, extirpation of osteophytes, and, in low-motion joints, arthrodesis and fenestration.

The aim of surgical curettage of cartilage and subchondral bone in an osteoarthritic joint is to promote healing of degenerate articular cartilage by fibrocartilaginous replacement tissue (Riddle 1970), but the quality of such tissue has been questioned (Hurtig et al. 1988; Mcllwraith and Vachon 1988). Partial thickness chondrectomy down to smooth and solid cartilage has therefore been advocated as this may ensure a better quality of the remaining articular cartilage (Mcllwraith and Vachon 1988). Further to this, it has been shown in another experimental study that no significant changes occurred in articular cartilage opposing partial thickness lesions in equine carpal joints (Richardson and Clark 1990). Full thickness defects in the articular cartilage (erosive changes) should, on the other hand, be managed by subchondral bone drilling (forage) as this seems to im- 
prove the healing of the defects and the quality of the repair tissue (Vachon et al. 1986).

Cartilage resurfacing of experimentally induced osteochondral defects in horses by autogenous periosteal (Sullins et al. 1985; Vachon et al. 1991a, 1991b) or osteochondral grafts (Stover et al. 1989; Sullins et al. 1989) has been reported. The purpose of periosteal autografts is to improve the healing of cartilage defects by stimulating repair tissue that resembles hyaline cartilage more closely than the fibrocartilaginous tissue that follows simple curettage. It has been demonstrated that periosteum is more chondrogenic than perichondrium when transplanted intra-articularly in horses (Vachon et al. 1989), but cartilage resurfacing by periosteal autografts has been disappointing in experimental studies. The rationale for osteochondral grafting is to transplant viable hyaline cartilage and subchondral bone and to maintain the viability of the transplanted tissues, thus reestablishing a continuous articular cartilage surface. Results with osteochondral grafting have been variable, but this method as well as periosteal transplantation certainly opens new prospects to future research.

Cartilage resurfacing by transplantation of chondrocytes embedded in a fibrin matrix was recently reported (Hendrickson et al. 1994). In that study, chondrocyte transplantation to experimentally induced osteochondral defects resulted in repair tissue which had a significantly higher proportion of type II collagen, compared with control defects. This finding is a strong indication for the use of chondrocyte transplantation in cartilage resurfacing of equine osteoarthritic joints in the future, but clinical trials are needed before the method can be completely assessed.

Extirpation of osteophytes is seldom performed and should only be attempted if interference with joint motion can be anticipated (Mcl/wraith 1987a; Mcllwraith and Vachon 1988). Surgical arthrodesis has been described as a treatment of OA in low-motion joints, such as the proximal interphalangeal joint and distal intertarsal joints. The rationale for this treatment is that bony fusion of these joints may lead to athletic soundness. Results and different techniques of proximal interphalangeal arthrodesis have been reported (Schneider et al. 1978; Genetzky et al. 1981; Martin et al. 1984; Steenhaut et al. 1985; Caron et al. 1990). In the distal intertarsal joints, surgical arthrodesis has gained widespread use in the treatment of OA (bone spavin) (Adams 1970; Mackay and Liddell 1972; Edwards 1982; Wyn-Jones and May 1986).

The surgical technique of fenestration was originally adopted from human osteotomy procedures (Arnoldi et al. 1971), the aim being a reduction of the juxta-articular bone pressure. Fenestration has since been widely used in the management of bone spavin in Denmark, and results with this technique have been published (Sønnichsen and Svalastoga 1985; Jansson et al. 1995). A major advantage of this technique is the relatively short period of convalescence, compared with that of surgical arthrodesis (Jansson et al. 1995).

The above review of the various treatment methods of equine $O A$ has focused on contemporary therapeutic options, and methods of more historic interest such as the application of blisters and firing have not been the scope of this article and will therefore not be discussed in this context.

\section{Conclusion}

Although progress is constantly being made, a lot has yet to be learned about pathogenesis, early diagnosis and treatment of equine OA. The ability to make an early diagnosis of ongoing joint degeneration, combined with an understanding of the pathogenic mechanisms of cartilage degradation and how to control them therapeutically, will in the future undoubtedly improve the prognosis of horses suffering from $O A$.

\section{References}

Adams, O.R. (1970): Surgical arthrodesis for the treatment of bone spavin. J. Am. Vet. Med. Ass. 157, 1480-1485

Ahlengard, S., Tufvesson, G., Pettersson, H. and Andersson, T. (1978): Treatment of traumatic arthritis in the horse with intra-articular orgotein (Palosein ${ }^{\circledR}$ ). Equine Vet. J. 10, 122-124

Alwan, W.H., Carter, S.D., Bennett, D., May, S.A. and Edwards, G.B. (1990): Cartilage breakdown in equine osteoarthritis: measurement of keratan sulphate by an ELISA system. Res. Vet. Sci. 49, 56-60

Alwan, W.H., Carter, S.D., Dixon, J.B., Bennett, D., May, S.A. and Edwards, G.B. (1991a): Interleukin-l-like activity in synovial fluids and sera of horses with arthritis. Res. Vet. Sci. 51, 72-77

Alwan, W.H., Carter, S.D., Bennett, D. and Edwards, G.B. (1991b): Glycosaminoglycans in horses with osteoarthritis. Equine Vet. J. 23, 44-47

Arnoldi, C.C., Lemperg, R.K. and Linderholm, H. (1971): Immediate effect of osteotomy on the intramedullary pressure of the femoral head and neck in patients with degenerative osteoarthritis. Acta Orthop. Scand. 42, 357-365

Auer, J.A., Fackelman, G.E., Gingerich, D.A. and Fetter, A.W. (1980): Effect of hyaluronic acid in naturally occurring and experimentally induced osteoarthritis. Am. J. Vet. Res. 41, 568-574

Auer, D.E. (1989): An hypothesis on the etio-pathogenesis of equine inflammatory joint disease. Vet. Clin. Path. 18, 21-26

Barbee, D.D. and Allen, J.R. (1990): Computed tomography and gamma scintigraphy. In: White II, N.A. and Moore, J.N. (Eds): Current practice of equine surgery. J.B. Lippincott Co, Philadelphia, 43-50

Caron, J.P. (1992): Understanding the pathogenesis of equine osteoarthritis. Br. Vet. J. 148, 369-371

Caron, J.P., Fretz, P.B., Bailey, J.V. and Barber, S.M. (1990): Proximal interphalangeal arthrodesis in the horse: a retrospective study and a modified screw technique. Vet. Surg. 19, 196-202

Caron, J.P., Eberhart, S.W. and Nachreiner, R. (1991): Influence of polysulfated glycosaminoglycan on equine articular cartilage in explant culture. Am. J. Vet. Res. 52, 1622-1625

Caron, J.P., Bowker, R.M., Abhold, R.H., Toppin, D.S., Sonea, I.M. and Vex, K.B. (1992): Substance $P$ in the synovial membrane and fluid of the equine middle carpal joint. Equine Vet. J. 24, 364-366

Caron, J.P., Toppin, D.S. and Block, J.A. (1993): Effect of polysulfated glycosaminoglycan on osteoarthritic equine articular cartilage in explant culture. Am. J. Vet. Res. 54, 1116-1121 
Chambers, M.D., Martinelli, M.J., Baker, G.J., Kneller, S.K. and Twardock, A.R. (1995): Nuclear medicine for diagnosis of lameness in horses. J. Am. Vet. Med. Ass. 206, 792-796

Chrisman, O.D., Ladenbauer-Bellis, I.M. and Panjabi, M. (1981): The relationship of mechanical trauma and the early biochemical reactions of osteoarthritic cartilage. Clin. Orthop. Rel. Res. J.B. Lippincott Co, Philadelphia, 275-284

Chunekamrai, S., Krook, L.P., Lust, G. and Maylin, G.A. (1989): Changes in articular cartilage after intra-articular injections of methylprednisolone acetate in horses. Am. J. Vet. Res. 50, 1733-1741

Cleland, L.G. (1984): Oxy radicals, "peroxide tone" and inflammation. J. Rheumatol. 11, 725-726

Clyne, M.J. (1987): Pathogenesis of degenerative joint disease. Equine Vet. J. 19, 15-18

Collins, E.A. (1989): Use of polysulphated glycosaminoglycan in equine lameness. Vet. Rec. 124, 89-90

Devous, M.D. and Twardock, A.R. (1984): Techniques and applications of nuclear medicine in the diagnosis of equine lameness. J. Am. Vet. Med. Ass. 184, 318-325

Edwards, G.B. (1982): Surgical arthrodesis for the treatment of bone spavin in 20 horses. Equine Vet. J. 14, 117-121

Genetzky, R.M., Schneider, E.J., Butler, H.C. and Guffy, M.M. (1981): Comparison of two surgical procedures for arthrodesis of the proximal interphalangeal joint in horses. J. Am. Vet. Med. Ass. 179, 464-468

Gingerich, D.A., Auer, J.A. and Fackelman, G.E. (1981): Effect of exogenous hyaluronic acid on joint function in experimentally induced equine osteoarthritis: dosage titration studies. Res. Vet. Sci. 30 , 192-197

Glade, M.J. (1990): Polysulfated glycosaminoglycan accelerates net synthesis of collagen and glycosaminoglycans by arthritic equine cartilage tissues and chondrocytes. Am. J. Vet. Res. 51, 779-785

Gängel, H. and Rahn, A. (1992): Zur Frage der diagnostischen Verwertbarkeit der Enzymaktivitäten in der Synovia bei Gelenkerkrankungen des Pferdes (in German with English summary). Mh. Vet. Med. 47, 17-24

Hamm, D. and Wynn Jones, E. (1988): Intra-articular (IA) and intramuscular (IM) treatment of noninfectious equine arthritis (DJD) with polysulfated glycosaminoglycan (PSGAG). Equine Vet. Sci. 8, 456-459

Hendrickson, D.A., Nixon, A.J., Grande, D.A., Todhunter, R.J., Minor, R.M. Erb, H. and Lust, G. (1994): Chondrocyte-fibrin transplants for resurfacing extensive articular cartilage defects. J. Orthop. Res. 12, 485-497

Howard, R.D. and MCllwraith, C.W. (1993): Sodium hyaluronate in the treatment of equine joint disease. Comp. Cont. Educ. Pract. Vet. $15,473-481$

Hurtig, M.B., Fretz, P.B., Doige, C.E. and Schnurr, D.L. (1988): Effects of lesion size and location on equine articular cartilage repair. Can. J. Vet. Res. 52, 137-146

Jansson, N., Sonnichsen, H.V. and Hansen, E. (1995): Bone spavin in the horse: fenestration technique - a retrospective study. Pferdeheilk. 11, 97-100

Jeffcott, L.B., Rossdale, P.D., Freestone, J., Frank, C.J. and TowersClark, P.F. (1982): An assessment of wastage in thoroughbred racing from conception to 4 years of age. Equine Vet. J. 14, 185-198

Jonsson, K., Buckwalter, K., Helvie, M., Niklason, L. and Martel, W. (1992): Precision of hyaline cartilage thickness measurements. Acta Radiol. 33, 234-239

Jørgensen, B.I. (1994): Ultrasonographic investigation of fetlock and hock joints in the horse: visualization of cartilage, synovial membrane and ligaments. Proc. 17 th Nord. Vet. Congr., 55

Lamb, C.R. and Koblik, P.D. (1988): Scintigraphic evaluation of skeletal disease and its application to the horse. Vet. Radiol. 29, 16-27

Lindholm, A. (1987): The intraarticular use of a combination of sodium hyaluronate and corticosteroids (in Swedish with English summary). Svensk Vet. Tidn. 39 (Suppl 14), 47-49
Little, C.B., Hilbert, B.J., Wickstrom, S. and Hedland, B.E. (1990): Quantitative microanalysis of equine synovial fluid glycosaminoglycan concentration. Am. J. Vet. Res. 51, 1534-1539

Little, C.B., Bonnett, B.N., Hilbert, B.J., Zoschke, D.C. and Wickstrom, S. (1992): Scavenging of hydrogen peroxide by equine synovial fluid. Aust. Equine Vet. 10, 88-89

Mackay, R.C.J. and Liddell, W.A. (1972): Arthrodesis in the treatment of bone spavin. Equine Vet. J. 4, 34-36

Madsen, J.S., Jensen, L.T., Strøm, H., Hørslev-Petersen, K. and Svalastoga, E. (1990): Procollagen type-III aminoterminal peptide in serum and synovial fluid of dogs with hip dysplasia and coxarthrosis. Am. J. Vet. Res. 51, 1544-1546

Martin, G.S., Mcllwraith, C.W., Turner, A.S., Nixon, A.J. and Stashak, T.S. (1984): Long-term results and complications of proximal interphalangeal arthrodesis in horses. J. Am. Vet. Med. Ass. 184 1136-1140

May, S.A., Hooke, R.E. and Lees, P. (1992a): Equine chondrocyte activation by a variety of stimuli. Br. Vet. J. 148, 389-397

May, S.A., Hooke, R.E. and Lees, P. (1992b): Interleukin-1 stimulation of equine articular cells. Res. Vet. Sci. 52, 342-348

May, S.A., Hooke, R.E. and Lees, P. (1992c): Inhibition of interleukin-1 activity by equine synovial fluid. Equine Vet. J. 24, 99-102

Mc/lwraith, C.W. (1982): Current concepts in equine degenerative joint disease. J. Am. Vet. Med. Ass. 180, 239-250

Mcllwraith, C.W. (1987a): Traumatic arthritis. In: Stashak, T.S. (Ed): Adams' lameness in horses. 4th ed. Lea and Febiger, Philadelphia, 360-396

Mcllwraith, C.W. (1987b): Diagnosis of joint disease. In: Stashak, T.S. (Ed): Adams' lameness in horses. 4th ed. Lea and Febiger, Philadelphia, 347-357

Mcl/wraith, C.W. (1990): General technique and diagnostic arthroscopy. In: Mcllwraith, C.W.: Diagnostic and surgical arthroscopy in the horse. Lea and Febiger, Philadelphia, 21-32

Mc/lwraith, C.W. (1993): Equine synovial fluid analysis and correlation with histopathologic and arthroscopic changes. Proc. 44th Ann. Meeting Am. Coll. Vet. Path., 9-16

Mcllwraith, C.W. and Vachon, A. (1988): Review of pathogenesis and treatment of degenerative joint disease. Equine Vet. J. 20 (Suppl 6), 3-11

Morris, E.A., McDonald, B.S., Webb, A.C. and Rosenwasser, L.J. (1990): Identification of interleukin-I in equine osteoarthritic joint effusions. Am. J. Vet. Res. 51, 59-64

Morris, E.A., Wilcon, S. and Treadwell, B.V. (1992): Inhibition of interleukin I-mediated proteoglycan degradation in bovine articular cartilage explants by addition of sodium hyaluronate. Am. J. Vet. Res. 53, 1977-1982

Morris, E.A. and Treadwell, B.V. (1994): Effect of interleukin 1 on articular cartilage from young and aged horses and comparison with metabolism of osteoarthritic cartilage. Am. J. Vet. Res. 55, 138-146

Niebaver, G.W., Wolf, B., Yarmush, M. and Richardson, D.W. (1988): Evaluation of immune complexes and collagen type-specific antibodies in sera and synovial fluids of horses with secondary osteoarthritis. Am. J. Vet. Res. 49, 1223-1227

O'Brien, T.R., Morgan, J.P., Park, R.D. and Lebel, J.L. (1971): Radiography in equine carpal lameness. Cornell Vet. 61, 646-660

Palmer, J.L. and Bertone, A.L. (1994): Joint structure, biochemistry and biochemical disequilibrium in synovitis and equine joint disease. Equine Vet. J. 26, 263-277

Pool, R.R. and Meagher, D.M. (1990): Pathologic findings and pathogenesis of racetrack injuries. Vet. Clin. North Am. 6, 1-30

Price, J.S., Symons, J.A. and Russell, R.G.G. (1992): Cytokines: inflammatory mediators of joint disease. Equine Vet. J. 24, 78-80

Purohit, R.C. (1980): The diagnostic value of thermography in equine medicine. Proc. Am. Ass. Equine Pract., 26th Ann. Conv., 317-326

Purohit, R.C. and MCCoy, M.D. (1980): Thermography in the diagnosis of inflammatory processes in the horse. Am. J. Vet. Res. 41, 1167-1174 
Rejnö, S. (1976): LDH and LDH isoenzymes of synovial fluid in the horse. Acta Vet. Scand. 17, 178-189

Richardson, D.W. and Clark, C.C. (1990): Biochemical changes in articular cartilage opposing full- and partial-thickness cartilage lesions in horses. Am. J. Vet. Res. 51, 118-122

Riddle, W.E. (1970): Healing of articular cartilage in the horse. J. Am. Vet. Med. Ass. 157, 1471-1479

Rose, R.J. (1979): The intra-articular use of sodium hyaluronate for the treatment of osteo-arthrosis in the horse. NZ Vet. J. 27, 5-8

Rossdale, P.D., Hopes, R., Wingfield Digby, N.J. and Offord. K. (1985): Epidemiological study of wastage among racehorses 1982 and 1983. Vet. Rec. 116, 66-69

Rydén, G., Ljungberg, L. and Pettersson, H. (1987): Palosein ${ }^{\circledast}$, sodium hyaluronate and synovia transplantation - a comparative clinical survey (in Swedish with English summary). Svensk Vet. Tidn. 39 (Suppl 14), 50-55

Rørvik, A.M. and Grondahl, A.M. (1995): Markers of osteoarthritis: a review of the literature. Vet. Surg. 24, 255-262

Schneider, J.E., Carnine, B.L. and Guffy, M.M. (1978): Arthrodesis of the proximal interphalangeal joint in the horse: a surgical treatment for high ringbone. J. Am. Vet. Med. Ass. 173, 1364-1369

Schwierczena, J., Fischer, D., Küpper, W. and Greiling, H. (1993): Synovia-Analyse bei Gelenkpaaren mit unterschiedlicher histologischer Befundung (in German with English summary). Pferdeheilk. 9, 315-317

Shinmei, M., Inamori, Y., Yoshiwara, Y., Kikuchi, T., Hayakawa, T. and Shimomura, Y. (1991): Molecular markers of joint disease: significance of the levels of type II collagen C-propeptide, chondroitin 46/68 and TIMP in synovial fluid. Trans. Orthop. Res. Soc. 16,443

Shoemaker, R.S., Bertone, A.L., Martin, G.S., Mcllwraith, C.W., Roberts, E.D., Pechman, R. and Kearney, M.T. (1992): Effects of intraarticular administration of methylprednisolone acetate on normal articular cartilage and on healing of experimentally induced osteochondral defects in horses. Am. J. Vet. Res. 53, 1446-1453

Steenhaut, M., Verschooten, F. and De Moor, A. (1985): Arthrodesis of the pastern joint in the horse. Equine Vet. J. 17, 35-40

Stover, S.M., Pool, R.R. and Lloyd, K.C.K. (1989): Repair of surgically created osteochondral defects with autogenous sternal osteochondral grafts in the horse. Vet. Surg. 18, 76-77

Sullins, K.E., Mcllwraith, C.W., Powers, B.E. and Norrdin, R.W. (1985): Evaluation of periosteal grafts in articular cartilage repair in horses. Vet. Surg. 14, 66-67

Sullins, K.E., Veit, H.P. and Mcllwraith, C.W. (1989): Osteochondral grafts to fill large articular defects in horses. Vet. Surg. 18, 77

Sønnichsen, H.V. and Svalastoga, E. (1985): Surgical treatment of bone spavin in the horse. Equine Pract. 7, 6-9

Tew, W.P. (1982): Synovial fluid analysis: applications in equine joint injury and disease. Proc. Am. Ass. Equine Pract., 28th Ann. Conv., 121-127

Thorén-Tolling, K., Tufvesson, G. and Wilhelmsson, J. (1983): Synovial fluid analysis in the diagnosis of some equine joint diseases (in Swedish with English summary). Svensk Vet. Tidn. 35 (suppl 3), 147-152

Todhunter, R.J. and Lust, G. (1990): Pathophysiology of synovitis: clinical signs and examination in horses. Comp. Cont. Educ. Pract. Vet. 12, 980-992

Todhunter, R.J., Yeager, A.E., Freeman, K.P., Parente, E.J. and Lust, $G$. (1993a): Keratan sulfate as a marker of articular cartilage catabolism and joint treatment in ponies. Am. J. Vet. Res. 54, 1007-1016

Todhunter, R.J., Freeman, K.P., Yeager, A.E. and Lust, G. (1993b): Effects of exercise and polysulfated glycosaminoglycan on the development of osteoarthritis in equine carpal joints with osteochondral defects. Vet. Surg. 22, 330-342
Todhunter, R.J. and Lust, G. (1994): Polysulfated glycosaminoglycan in the treatment of osteoarthritis. J. Am. Vet. Med. Ass. 204, 1245-1251

Trotter, G.W., Mcllwraith, C.W., Yovich, J.V., Norrdin, R.W., Wrigley, R.H. and Lamar, C.H. (1991): Effects of intra-articular administration of methylprednisolone acetate on normal equine articular cartilage. Am. J. Vet. Res, 52, 83-87

Vachon, A., Bramlage, L.R., Gabel, A.A. and Weisbrode, S. (1986): Evaluation of the repair process of cartilage defects of the equine third carpal bone with and without subchondral bone perforation. Am. J. Vet. Res. 47, 2637-2645

Vachon, A.M., Mcllwraith, C.W., Trotter, G.W., Norrdin, R.W. and Powers, B.E. (1989): Neochondrogenesis in free intra-articular periosteal and perichondrial autografts in the horse. Vet. Surg. 18, 77

Vachon, A.M., Keeley, F.W., Mcllwraith, C.W. and Chapman, P. (1990): Biochemical analysis of normal articular cartilage in horses. Am. J. Vet. Res. 51, 1905-1911

Vachon, A.M., Mcllwraith, C.W., Trotter, G.W., Norrdin, R.W. and Powers, B.E. (1991a): Morphologic study of induced osteochondral defects of the distal portion of the radial carpal bone in horses by use of glued periosteal autografts. Am. J. Vet. Res. 52, 317-327

Vachon, A.M., Mcllwraith, C.W. and Keeley, F.W. (1991b): Biochemical study of repair of induced osteochondral defects of the distal portion of the radial carpal bone in horses by use of glued periosteal autografts. Am. J. Vet. Res. 52, 328-332

Vaden, M.F., Purohit, R.C., McCoy, M.D. and Vaughan, J.T. (1980): Thermography: a technique for subclinical diagnosis of osteoarthritis. Am. J. Vet. Res. 41, 1175-1179

VanSteenhouse, J.L. (1987): Free radicals: relation to tissue damage a review. Vet. Clin. Path. 16, 29-35

Wagner, A.E., Mcllwraith, C.W. and Martin, G.S. (1982): Effect of intra-articular injection of orgotein and saline solution on equine synovia. Am. J. Vet. Res. 43, 594-597

Wyn-Jones, G. and May, S.A. (1986): Surgical arthrodesis for the treatment of osteoarthrosis of the proximal intertarsal, distal intertarsal and tarsometatarsal joints in 30 horses: a comparison of four different techniques. Equine Vet. J. 18, 59-64

Yovich, J.V., Trotter, G.W., Mcllwraith, C.W. and Norrdin, R.W. (1987): Effects of polysulfated glycosaminoglycan on chemical and physical defects in equine articular cartilage. Am. J. Vet. Res. 48, $1407-1414$

Nicolai Jansson, DVM, PhD

Present address:

Department of Clinical Sciences

College of Veterinary Medicine

Cornell University

Ithaca, New York 14853 